\title{
Penerapan Linguistik Arab Dalam Memahami Bahasa Al-Qur'an
}

\begin{abstract}
Abdul Kosim ${ }^{1}$
DOI: https://doi.org/10.52593/klm.01-1-02

Naskah diterima: 17-05-2020, direvisi: 02-07-2020, disetujui: 10-07-2020

\section{Abstraksi}

Penelitian ini menjelaskan fenomena penerapan linguistik Arab dalam memahami bahasa Al-Qur'an pada guru Bahasa Arab Madrasah Aliyah Kabupaten Purwakarta. Data dalam penelitian ini diperoleh dari beberapa sampel guru Bahasa Arab dari 12 Madrasah Aliyah yang ada di Kabupaten Purwakarta. Metode yang digunakan dalam penelitian ini adalah metode deskriptif kualitatif. Penerapan linguistik Arab yang meliputi aspek-aspek internal bahasa dari mulai fonologi, morfologi, sintaksis, dan semantik yang tampak pada guru Bahasa Arab Madrasah Aliyah di Kabupaten Purwakarta menunjukkan $76 \%$ sudah sesuai dengan kaidah linguistik. Nilai yang cukup besar dan didominasi aspek fonologi sebesar 22\%, disusul dengan aspek sintaksis 18,3\%, aspek morfologi yang 18,3\%, dan aspek semantik yang 17\%. Secara umum guru bahasa Arab Madrasah Aliyah Kabupaten Purwakarta dalam hal penerapan linguistik Arab untuk memahami bahasa Al-Qur'an sangat bagus, hal ini disebabkan karena kualitas sumber daya manusia yang memadai dan lingkungan yang mendukung karena dikelililngi oleh pesantren-pesantren yang hebat dan berkualitas.
\end{abstract}

Kata kunci: Al-Qur'an, Bahasa, Linguistik

\section{A. Pendahuluan}

Al-Qur'an merupakan kitab suci umat Islam yang sangat monumental, kehadirannya begitu strategis sebagai pedoman hidup yang komprehensif dan universal. Unsur-unsur kehidupan manusia dari mulai urusan-urusan pribadi, sosial dan peribadahan semuanya terangkum dalam Al-Qur'an. Al-Qur'an adalah firman Allah swt. yang diturunkan kepada Nabi Muhammad saw. dan bagi orang yang membacanya merupakan suatu amal ibadah ${ }^{2}$.

Pengertian tersebut secara jelas menegaskan bahwa Al-Qur'an bukan produk manusia melainkan firman Tuhan dengan karakter bahasa dan keindahannya yang tidak

\footnotetext{
${ }^{1}$ STAI Dr. KHEZ. Muttaqien Purwakarta, abdoelmahir87@yahoo.com

${ }^{2}$ Mana Khalil Al-Qathan, Mabahits fi Ulum Al-Qur'an, Terjemahan Aunur Rafiq El-Mazni. (Jakarta Timur: Pustaka Al-Kautsar, 2005), 18-19
} 
tertandingi oleh kemampuan manusia. Al-Qur'an diturunkan secara bertahap melalui Malaikat Jibril a.s. kepada Nabi Muhammad saw., susunanya dimulai dari surat AlFatihah dan diakhiri dengan surat An-Nass, fungsinya menjadi bukti yang kuat (hujjah) atas kerasulan Nabi Muhammad saw. Keberadaannya hingga kini masih tetap terpelihara dengan baik dan penyebarannya dilakukan secara berantai dari satu generasi ke generasi lain dengan tulisan maupun lisan $^{3}$. Al-Qur'an merupakan anugerah dari Allah swt. bagi umat Islam, eksistensinya dijamin hingga akhir zaman. Allah Swt. berfirman:

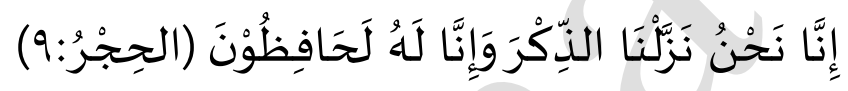

Artinya:

"Sesungguhnya Kami-lah yang menurunkan Alquran, dan pasti kami (pula) yang memeliharanya (Q.S. Al-Hijr: 9).

Al-Qur'an diturunkan menggunakan bahasa Arab, alasannya karena Nabi Muhammad saw. yang menyampaikan dan masyarakat pertama yang ditemuinya menggunakan bahasa $\mathrm{Arab}^{4}$. Selain itu, bahasa Arab yang menjadi bahasa Al-Qur'an dipilih atas dasar keunikan dan kekayaannya, lebih banyak karena faktor teknis penyampaiannya bukan karena etnis atau suku bangsa ${ }^{5}$. Al-Qur'an sekalipun berbahasa Arab, tetapi ajarannya universal bukan bahasa khusus umat Islam atau agama Islam saja, melainkan digunakan juga oleh penganut agama non -Muslim yang sampai sekarang bermukim di beberapa wilayah Arab.

Kehadiran Al-Qur'an sebagai jalan hidup (way of life) bagi umat Islam di seluruh dunia menuntut mereka agar senantiasa berupaya untuk membaca, mempelajari dan memahami pesan yang terkandung di dalamnya, sehingga mampu merealisasikannya dalam kehidupan sehari-hari. Selain itu membaca, memahami dan menghayati Alquran adalah salah satu cara guna meningkatkan kualitas iman seorang muslim ${ }^{6}$.

Selain sebagai pedoman hidup bagi umat Islam, Al-Qur'an juga merupakan mukjizat yang diberikan kepada Nabi Muhammad saw sebagai bukti yang sangat kuat

\footnotetext{
${ }^{3}$ Abudin Nata, Metodologi Studi Islam. (Depok: PT. Rajagrafindo Persada, 2012), 69

${ }^{4}$ Muhammad Amin Suma, Ulumul Qur'an. (Jakarta: Rajawali Press, 2013), 23

${ }^{5}$ M. Quraish Shihab, Kaidah Tafsir. (Tangerang: Lentera Hati, 2011), 542

${ }^{6}$ Ibid, 49
} 
atas kebenarannya selaku utusan Allah swt. dengan menampakkan kelemahan orang Arab dan kelemahan generasi-generasi sesudah mereka. Mukjizat adalah sesuatu hal yang luar biasa, bisa mengalahkan lawan serta bisa menyelamatkan dari gangguan lawan ${ }^{7}$. Kehebatan Alquran sebagai mukjizat digunakan Nabi untuk menantang orangorang Arab, terutama yang mengatakan Al-Qur'an itu buatan Nabi Muhammad dan produk manusia, mereka tidak sanggup menghadapi kehebatan Al-Qur'an, sedemikian tinggi tingkat kefasihannya (fasahah) dan juga memiliki nilai sastra (balagah) nya yang sangat tinggi. Allah swt. berfirman:

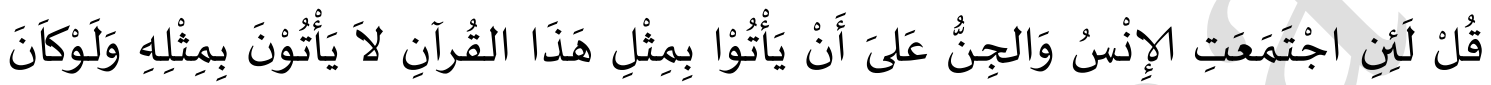

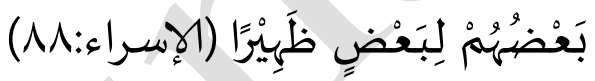

Artinya:

"Katakanlah: Sesungguhnya jika manusia dan jin berkumpul untuk membuat yang serupa (dengan) Al-Qur'an ini, mereka tidak akan dapat membuat yang serupa dengannya, sekalipun mereka saling membantu satu sama lain”. (Q.S. Al-Israa: 88)

Kemukjizatan Al-Qur'an terletak pada aspek kebahasaannya, aspek ilmiah dan aspek hukumnya (tasyri'). Kemukjizatan Al-Qur'an dari aspek bahasa terletak dalam keteraturan bunyinya yang indah melalui nada huruf-hurufnya, sehingga telinga tidak pernah bosan, bahkan ingin senantiasa terus mendengarnya. Dari segi lafadznya yang memenuhi hak setiap makna pada tempatnya, tidak satupun diantara lafadz-lafadznya yang dikatakan sebagai kelebihan. Dari segi strukturnya Al-Qur'an berbeda dengan urutan yang umum yang telah dikenal luas dalam perkataan orang Arab. Orang Arab tidak mempunyai struktur (kalam) yang memiliki rekayasa yang indah, makna yang halus, manfaat yang melimpah, hikmah yang meruah, dan keserasian nilai sastra sebanyak dan sedalam Al-Qur'an. Kemukjizatan ilmiah Al-Qur'an terletak pada dorongan untuk berfikir dan menggunakan akal. Persoalan atau kaidah ilmu pengetahuan yang telah mantap dan meyakinkan merupakan manifestasi dari pemikiran valid yang dianjurkan Al-Qur'an. Adapun kemukjizatan dari aspek hukumnya (tasyri') merupakan pedoman syariat yang paripurna yang menegakan kehidupan manusia di atas

\footnotetext{
${ }^{7}$ Mana Khalil Al-Qathan, Mabahits fi Ulum Al-Qur'an, Terjemahan Mudzakir As. (Jakarta: Litera Antarnusa, 2000), 371
} 
dasar konsep yang paling utama, kemudian Al-Qur'an telah memberikan pengaruh besar yang dapat mengubah wajah sejarah dunia ${ }^{8}$.

Keindahan Al-Qur'an dari segi bahasa terletak pada aspek fonologi (al-mustawa al-sauti), semantik (al-mustawa al-dalaili), dan struktur/ sintaksis (al-mustawa altarkiby $^{9}$ ). Redaksi dalam Al-Qur'an merupakan fenomena kebahasaan yang sangat menarik untuk diteliti dari berbagai aspek, hal ini tidak akan pernah habis dan selesai, bergantung pada sejauh mana akal dan kemampuan intelektual manusia dalam menggalinya.

Pemahaman terhadap Al-Qur'an bisa dilakukan dengan pendekatan ilmu bahasa atau linguistik. Unsur-unsur linguistik yang mencakup fonologi, morfologi, sintaksis dan semantik merupakan salah satu unsur terpenting dan sebagai jembatan untuk memahami kandungan Al-Qur'an. Contohnya dalam asfek fonologi sebuah bunyi mempengaruhi makna sebuah kata, perhatikan firman Allah dalam Alquran surat Thaha ayat 96:

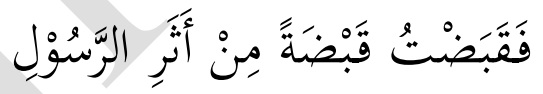

Artinya:

"Aku ambil segenggam (tanah dari) jejak rasul”

Kata قبض dari segi pelafalan merupakan kata yang agak berat untuk dilafalkan, ternyata maknanya adalah menggenggam dengan seluruh jari tangan, karena ada padanan katanya yaitu قبص yang agak ringan pelafalannya mengandung arti memegang hanya dengan ujung jari-jari saja ${ }^{10}$.

Dari aspek morfologi kita bisa menyaksikan salah satunya dalam firman Allah dalam Al-Qur'an surat Al-Imran ayat 3:

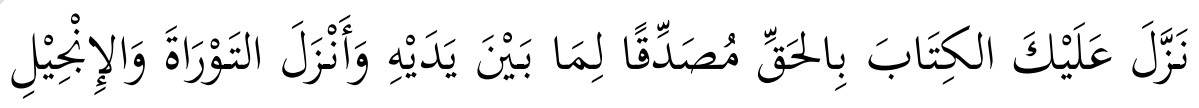

Artinya:

"Dia menurunkan kitab (Al-Qur'an) kepadamu (Muhammad) yang mengandung kebenaran, membenarkan (kitab-kitab) sebelumnya dan menuruntan Tauret dan Inzil"

\footnotetext{
${ }^{8}$ Ibid

${ }^{9}$ Syihabuddin Qalyubi, Stilistika Bahasa dan Sastra Arab. (Yogyakarta: Karya Media, 2013), 90

${ }^{10}$ Mahmud Ukasah, At-Tahlil Al-Lughawy. (Kairo: Daar Ibnu Hazam, 2011), 31
} 
Pilihan kata yang dipilih untuk Al-Qur'an adalah نزّ sedangkan untuk kitab Taurat dan Injil adalah أنزل. Secara morfologis makna kata نزّل adalah taktsir yang artinya pekerjaan yang dilakukan secara berulang-ulang, artinya Al-Qur'an diturankan secara berulang-ulang atau berangsur-angsur. Kemudian kata أنزل artinya menurunkan secara sekaligus ${ }^{11}$.

Uraian di atas merupakan salah satu contoh pentingnya pemahaman terhadap ilmu Bahasa (linguistik) sebagai gerbang untuk memamahami kandungan Al-Qur'an secara utuh dan kesadaran akan kemukjizatan Bahasa yang ada dalam Al-Qur'an.

\section{B. Teori / Konsep}

Bahasa merupakan unsur penting yang tidak bisa dipisahkan dari kehidupan masyarakat, karena bahasa merupakan alat komunikasi yang menyambungkan antara satu individu dengan individu lainnya. Bahasa adalah bunyi-bunyi yang digunakan oleh sekelompok orang untuk mengungkapkan tujuan-tujuan mereka (dalam

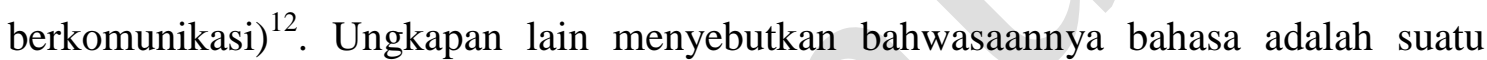
sistem yang arbitrer berupa simbol bunyi yang digunakan untuk bertukar pikiran ${ }^{13}$. Dari penjelasan tersebut bahasa merupakan suatu sistem yang meliputi ujaran bunyi dan pesan makna yang disampaikan oleh orang yang menggunakannya. Mengingat pentingya bahasa dalam kehidupan manusia, maka kajian dan penelitian bahasa terus berkembang baik mikro ataupun makro. Ilmu yang secara umum mengkaji tentang bahasa dan kaidah-kaidahnya disebut linguistik. Linguistik adalah ilmu tentang bahasa atau kajian ilmiah tentang bahasa ${ }^{14}$. Linguistik adalah ilmu yang membahas tentang bahasa dari seluruh aspeknya, meliputi bunyi, bentuk, struktur, aplikatif, kosakata, dan leksikalnya ${ }^{15}$. Penjelasan tersebut menggambarkan bahwasannya linguistik menyentuh unsur-unsur yang melekat pada bahasa, baik secara internal maupun eksternal. Dalam penelitian ini unsur linguistik yang dijadikan acuan atau indikatornya adalah unsur internal bahasa yang meliputi fonologi, morfologi, sintaksis, dan semantik.

\section{Aspek Fonologi}

\footnotetext{
${ }^{11}$ Fadil Shalih As-Samira'I, Balaghatu Al-Kalimat Fi At-Ta'biri Al-Qur'ani. (Bagdad: Universitas AlAzhar, 2006), 60

${ }^{12}$ Ibnu Jinni, Al-Khasa 'is. (Mesir: Daar Al-Kutub, 1913), 33

${ }^{13}$ Muhammad Ali Al-Khuli, A Dictionary of Theoretical Linguistics. (Beirut: Librarie di Liban, 1991), 148

${ }^{14}$ Harimurti Kridalaksana, Kamus Linguistik. (Jakarta: PT Gramedia, 2009), 144

${ }^{15}$ Muhammad Ali Al-Khuli, A Dictionary of Theoretical Linguistics. (Beirut: Librarie di Liban, 1991), 157
} 
Fonologi adalah cabang ilmu bahasa (linguistik) yang mengkaji bunyi-bunyi bahasa, proses terbentuknya dan perubahannya ${ }^{16}$. Dalam fonologi kita mengenal adanya istilah Fonetik. Fonetik adalah cabang ilmu linguistik yang mempelajari dan meneliti dasar dasar fisik bunyi-bunyi bahasa tanpa melihat fungsi bunyi itu sebagai pembeda makna atau tidak dalam suatu bahasa ${ }^{17}$. Selain fonetik dalam fonologi ada juga yang disebut dengan fonem. Fonem adalah suatu bunyi yang membedakan arti kata dari kata yang lain atau semua bunyi yang dapat membedakan makna kata. Contoh dalam bahasa Indonesia kita lihat kata saku, laku, paku, kaku. Kita melihat keempat kata ini memilki bunyi /aku/, yang berbeda hanyalah perbedaan bunyi awalnya. Dalam bahasa Arab misalnya kata; جبن ,جبل جبر. Pada contoh bagian pertama kita melihat dengan bunyi awal yang berbeda itu bisa mengakibatkan makna kata tersebut menjadi berbeda, dan pada contoh bagian kedua bunyi terakhir dari kata itu berbeda dan semuanya berakibat pada bedanya makna dari kata tersebut. Dengan demikian kita bisa mengatakan bahwa ada fonem /1,s,p,k/ pada keempat kata tersebut dan fonem $\mathrm{r}$, 1, dan fonem $\mathrm{n}$ pada contoh bahasa Arab tersebut.

Fonem dibagi menjadi dua bagian, yaitu fonem segmental (fûnimât altarkîbiyyah) adalah fonem yang dapat dianalisis keberadaannya. Sedangkan fonem suprasegmental (Fûnimât ma fauqa al-tarkîb)l; Fonem yang keberadaannya harus bersama-sama fonem segmental.

Fonem segmental terbagi pada dua bagian yaitu vokal dan konsonan. Perbedaan antara vokal dan konsonan hanya terletak pada ada tidaknya halangan ketika bunyibunyi itu difonasikan. Kalau bunyi itu mendapat halangan ketika difonasikan maka itu adalah konsonan, dan apabila tidak mendapat halangan dan bunyi keluar dengan leluasa maka disebut vokal. Sementara itu yang termasuk pada katagori fonem supra segmental adalah $\boldsymbol{a l - N a b r}$ (stressing) dan Tanghîm (intonation).

a. Al-Nabr (stress)

Sepeti kita ketahui bahwa sebuah kata itu tersusun dari rangkaian bunyi yang saling berkaitan dan berurutan. Tetapi kita juga bisa mengamati bahwa bunyi-bunyi yang berurutan itu tidak sama dalam pengucapannya. Kadang dalam pengucapannya ada yang kuat, lemah dan ada yang sedang sesuai dengan tempat bunyi tersebut dalam

\footnotetext{
${ }^{16}$ Lina Marlina, Pengantar Ilmu Ashwat. (Bandung: Fajar Media, 2019), 19

${ }^{17}$ Ibid. 20
} 
sebuah kata. Bunyi atau bagian yang diucapkan dengan tingkat yang lebih kuat dinamakan dengan al-Nabr. Dengan demikian al-Nabr adalah bunyi yang kuat dan jelas yang terdapat dalam suatu kata dibanding dengan bunyi-bunyi lain yang berdampingan.

b. Tanghîm (intonation)

Al-Tanghîm atau intonasi adalah kuat dan lemahnya bunyi pada suatu kalimat atau disebut juga irama dalam berbicara. Kita sering mengamati bahwa pembicaraan seseorang itu berbeda-beda intonasinya sesuai dengan bagian-bagian struktur dan tempat dimana dia berhenti. Perbedaan intonasi ini akan membantu kita dalam memahami makna yang dimaksud dari pembicaraan itu sendiri.

Tanghîm mempunyai fungsi dalam pembentukan struktur kalimat dan makna. Satu kalimat yang kita jumpai bisa mempunyai makna taqrîri (penetapan) atau istifhâm (pertanyaan) karena pengungkapan kalimat tersebut dengan intonasi yang berbeda.

\section{c. Thuul al-Shaut (durasi)}

Durasi berarti panjang waktu relatif dipertahankannya alat-alat ucap pada suatu posisi. Bahasa-bahasa tertentu membedakan antara dua atau lebih rentang waktu bunyibunyi wicara. Panjang-pendek suatu bunyi (length) bahasa menunjukkan lama waktu dipertahankannya posisi alat ucap. Tentu saja panjang bunyi bahasa berbeda-beda. Dalam tulisan fonetik, tanda seperti : dan :: (length) dipakai sebagai pertanda panjang. Durasi di dalam bahasa Arab membedakan makna. Misalnya pada kata ka:taba, pengucapan konsonan $[\mathrm{K}]$ dengan menggunakan rentang waktu, dan kataba tanpa menggunakan waktu, sudah membuat kata tersebut berbeda maknanya. Yang pertama mempunyai makna 'saling berkirim surat', sementara yang kedua berarti 'menulis'. Kualitas berkaitan pula denga panjang-pendeknya suatu kata.

\section{Aspek Morfologi}

Morfologi adalah ilmu yang mempelajari bentuk kata dan perubahan bentuk kata serta makna yang muncul akibat perubahan bentuk itu ${ }^{18}$. Dalam literatur Arab kita bisa mendapatkan pengertian tentang sharaf itu sendiri sebagai berikut:

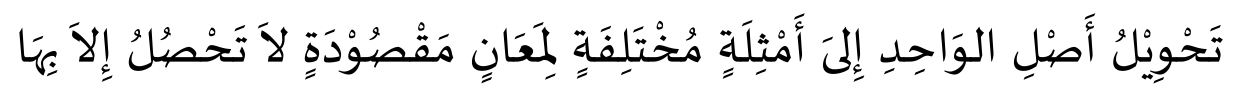

\footnotetext{
${ }^{18}$ Ade Nandang \& Abdul Kosim, Pengantar Linguistik Arab. (Bandung: PT Remaja Rosdakarya, 2018), 72
} 
Penerapan Linguistik Arab... (Abdul Kosim)

Artinya: "memindahkan/merubah satu kata pada bentuk-bentuk lain karena tujuan makna tertentu yang tidak akan berhasil kecuali dengan melakukan perubahan bentuk-bentuk tersebut".

Dari pengertian diatas ada tiga hal yang dipelajari dalam morfologi:

- Bentuk kata

- Perubahan bentuk kata

- Makna yang muncul akibat dari perubahan tersebut.

Berbicara mengenai sistem bentuk dalam bahasa Arab, Tamam Hasan menjelaskan bahwa sistem bentuk membicarakan tiga hal pokok yaitu:

1) Kumpulan makna sharfiyyah yang sebagian kembali pada pembagian kalam, sebagian kembali pada pembentukan pola (tashrîf).

2) Kumpulan bentuk-bentuk kata yang terdiri dari pola dasar, lawâshiq, zawâid, dan al-adawât.

3) Kumpulan hubungan antara bentuk-bentuk dengan nilai-nilai berbeda

\section{Aspek Sintaksis}

Sintaksis merupakan cabang linguistik yang mengkaji hubungan antarkata dalam suatu kontruksi ${ }^{19}$. Sintaksis dalam Bahasa Arab disebut dengan ilmu nahwu. Ilmu nahwu adalah ilmu yang mempelajari kedudukan sebuah kata ketika sudah berada dalam sebuah kalimat $^{20}$. Dengan demikian sintaksis merupakan ilmu yang mengkaji rangkaian kata-kata yang didistribusikan dalam sebuah kalimat dan memiliki makna yang sempurna.

Sintaksis dalam Bahasa Arab memiliki karakteristik tersendiri yang berbeda dengan sintaksis dalam bahasa yang lainnya. Diantaranya dalam Bahasa Arab sintaksis dirinci kembali menjadi ilmu tarkib atau ilmu tentang strukur. Struktur dalam Bahasa Arab diantaranya ada yang disebut dengan tarkib washfi dan tarkib idhafi. Tarkib washfi adalah susunan yang terdiri dari nomina dan adjektif contohnya محمد ماهر 'Muhammad yang pandai' sedangkan tarkib idhofi adalah susunan yang terdiri dari gabungan nomina dengan nomina contohnya رئيس المدرسة 'kepala sekolah'.

4. Aspek Semantik

${ }^{19}$ Ibid. 82

${ }^{20}$ Tajudin Nur, Sintaksis Bahasa Arab. (Sumedang: Unpad Press, 2018), 18 
Semantik merupakan sebuah istilah untuk bidang ilmu bahasa yang membahas tentang makna ${ }^{21}$. Semantik berarti teori makna atau teori arti yakni cabang sistematik bahasa yang menyelidiki makna atau arti. Dalam bahasa Arab ilmu tentang makna atau semantik disebut dengan 'Ilm al-Dilâlah. Dalam ilmu bahasa apa yang kita ujarkan sebenarnya terdiri dari deretan deretan bunyi yang kadang-kadang diucapkan cepat, lambat, tinggi bahkan menggunakan kalimat-kalimat yang panjang. Apa yang kita dengar sebenarnya mempunyai dua lapis, yakni lapis bentuk (disini berwujud bunyi) dan lapis makna, kalau kita meminjam istilah Ferdinant terdapat istilah signifiant dan signifie. Apa yang kita lihat berupa deretan kata merupakan lapis bentuk, sedangkan apa yang diamanatkan, apa yang dipesankan, apa yang ditunjukan, bahkan apa yang tersirat dalam satuan gramatika itu, semuanya merupakan lapis makna. Dan lapis makna itulah yang dibahas dalam semantik.

Seandainya kita mendengar kata "jagung" terbayang pada kita, apakah jagung itu?. Kalau ditanyakan komponen-komponennya dengan mudah kita sebutkan. Terbayang pada kita apa yang disebut jagung baik batangnya beruas-ruas, batangnya yang tidak berkayu, akarnya daunnya, buahnya yang berbiji. Itulah jagung. Jadi sekarang kita sudah mengetahui nama umum untuk jagung. Tetapi kalau kita sekarang tambah unsur berupa lima liter jagung, ternyata bahwa deretan kata itu tidak sama lagi dengan jagung.

\section{Metode Penelitian}

Metode yang digunakan dalam penelitian ini adalah metode deskriptif-kualitatif. Deskripsi bermanfaat untuk mengambarkan ciri-ciri data secara akurat sesuai dengan sifat alamiah itu sendiri ${ }^{22}$. Penelitian ini menggambarkan fenomena pemahaman guruguru bahasa Arab Madrasah Aliyah di Kabupaten Purwakarta. Populasi dalam penelitian ini adalah guru-guru bahasa Arab Madrasah Aliyah Kabupaten Purwakarta yang berjumlah 30 orang, adapun yang dijadikan sampel berjumlah 12 orang yang bersikap akomodatif dan kooperatif dalam mengisi soal-soal penelitian tentang

\footnotetext{
${ }^{21}$ Tajudin Nur, Semantik Bahasa Arab. (Bandung: Semiotika, 2017), 2

${ }^{22}$ Fatimah Djajasudarma, Metode Linguistik. (Bandung: Refika Aditama, 2010), 11
} 
penerpan linguistik Arab dalam memahami Al-Qur'an. Instrumen dalam penelitian ini berupa tes yang berupa soal-soal pilihan ganda yang berjumlah 20 soal.

\section{Penelitian dan Pembahasan}

Untuk mengetahui Penerapan Linguistik Arab dalam Memahami Bahasa AlQur'an pada guru bahasa Arab di Kabupaten Purwakarta, peneliti melakukan uji tes soal kepada sampel 12 guru bahasa Arab di Kabupaten Purwakarta, yaitu sebagai berikut:

\begin{tabular}{|l|l|}
\hline No. & \multicolumn{1}{|c|}{ Nama Sekolah } \\
\hline 1 & MA Al- Irfan \\
\hline 2 & MA Al- Ma'arif 1 \\
\hline 3 & MA Al- Muhajirin \\
\hline 4 & MA Al- Muta'alimin \\
\hline 5 & MA Darul Ilmi \\
\hline 6 & MA Hidayatul Muttaqien \\
\hline 7 & MA Ibnu Zain \\
\hline 8 & MA Khez Muttaqien \\
\hline 9 & MA Ma'arif \\
\hline 10 & MA Nurul Fata \\
\hline 11 & MA YPIA Cikeris \\
\hline
\end{tabular}

Untuk memperoleh hasil data penelitian, peneliti memberikan 20 butir soal pilihan ganda kepada responden. Dimana di dalam soal tersebut terbagi menjadi 
beberapa aspek atau kategori, yaitu kategori fonologi, sintaksis, morfologi dan semantik. Adapun indikator yang terdapat dalam setiap soal adalah sebagai berikut:

\begin{tabular}{|c|c|c|c|}
\hline No. & Indikator Soal & No. Soal & Materi Pokok \\
\hline 1. & $\begin{array}{l}\text { Melafalkan bunyi huruf dalam } \\
\text { salah satu ayat Al- Qur'an. }\end{array}$ & $1 \& 2$ & \\
\hline 2. & $\begin{array}{l}\text { Ketepatan melafalkan kata } \\
\text { dengan intonasi yang benar } \\
\text { dalam salah satu ayat Al- Qur'an. }\end{array}$ & 3 & \\
\hline 3. & $\begin{array}{l}\text { Menyebutkan contoh stressing } \\
\text { dalam salah satu ayat Al- Qur'an. }\end{array}$ & 4 & Fonologi \\
\hline 4. & $\begin{array}{l}\text { Menjelaskan maksud } \\
\text { penggunaan waqof kaafi dalam } \\
\text { salah satu ayat Al- Qur'an }\end{array}$ & 5 & \\
\hline 5. & $\begin{array}{l}\text { Menyebutkan makna wazan- } \\
\text { wazan fi'il dalam salah satu ayat } \\
\text { Al- Qur'an }\end{array}$ & $6 \& 7$ & \\
\hline 6. & $\begin{array}{l}\text { Menjelaskan fenomena ibdal } \\
\text { dalam kata lalam salah } \\
\text { satu ayat Al- Qur'an. }\end{array}$ & 8 & \\
\hline 7. & $\begin{array}{l}\text { Menjelaskan fenomena I'lal } \\
\text { dalam kata قائل dalam salah satu } \\
\text { ayat Al- Qur'an. }\end{array}$ & 9 & \\
\hline 8. & $\begin{array}{l}\text { Menyebutkan kata berimbuhan } \\
\text { (lawasiq) pada kata استغفر dalam } \\
\text { salah satu ayat Al- Qur'an. }\end{array}$ & 10 & \\
\hline
\end{tabular}


Penerapan Linguistik Arab... (Abdul Kosim)

\begin{tabular}{|c|c|c|c|}
\hline 9. & $\begin{array}{l}\text { Menyebutkan jabatan kata dan } \\
\text { struktur dalam salah satu ayat } \\
\text { Al- Qur'an. }\end{array}$ & 11 & \multirow{5}{*}{ Morfologi } \\
\hline 10. & $\begin{array}{l}\text { Menyebutkan I'rab sebuah kata } \\
\text { dalam salah satu ayat Al- Qur'an. }\end{array}$ & 12 & \\
\hline 11. & $\begin{array}{l}\text { Menyebutkan struktur dalam } \\
\text { salah satu ayat Al- Qur'an. }\end{array}$ & 13 & \\
\hline 12. & $\begin{array}{l}\text { Menyebutkan perbedaan makna } \\
\text { antara jumlah ismiyah dan } \\
\text { fi'liyah dalam salah satu ayat Al- } \\
\text { Qur'an. }\end{array}$ & 14 & \\
\hline 13. & $\begin{array}{l}\text { Menjelaskan makna yang } \\
\text { terkandung dalam fenomena } \\
\text { mendahulukan maf'ul dari pada } \\
\text { fi'il dan fa'il dalam salah satu } \\
\text { ayat Al- Qur'an. }\end{array}$ & 15 & \\
\hline 14. & $\begin{array}{l}\text { Menyebutkan kata yang } \\
\text { mengandung makna mustarak } \\
\text { dalam salah satu ayat Al- Qur'an. }\end{array}$ & $16 \& 17$ & \\
\hline 15. & $\begin{array}{l}\text { Menyebutkan } \begin{array}{c}\text { kata } \\
\text { mengandung } \\
\text { makna taraduf }\end{array} \\
\text { dalam salah satu ayat Al- Qur'an. }\end{array}$ & 18 & Semantik \\
\hline 16. & $\begin{array}{l}\text { Menyebutkan } \begin{array}{c}\text { kata } \\
\text { mengandung } \\
\text { makna } \\
\text { tadhad }\end{array} \\
\text { dalam salah satu ayat Al- Qur'an. }\end{array}$ & $19 \& 20$ & \\
\hline
\end{tabular}

Hasil analisis adalah berupa jawaban responden dari soal- soal yang telah diberikan peneliti, yang meliputi persentase kemampuan responden menjawab setiap 
Kalamuna, Vol. 1. No. 1 Juli 2020, 20 - 37

soalnya, persentase kemampuan secara perorangan, persentase kemampuan secara keseluruhan, dan persentase kemampuan setiap kategori soal.

Persentase bisa dihitung menggunakan rumus:

Persentase $=\frac{\text { Jumlah bagian }}{\text { Jumlah keseluruhan }} \times 100 \%$

Berikut langkah- langkah menghitung persentase kemampuan responden:

1. Persentase per- Soal

Persentase per- soal ini yaitu untuk mengetahui persentase terjawabnya setiap soal, sehingga kita bisa mengetahui seberapa persen soal tersebut bisa terjawab oleh responden, untuk mengetahui persentase tersebut kita harus menghitung terlebih dahulu jumlah benar setiap soal dari seluruh sampel, lalu dibagi sampel yaitu 12 orang. Atau bisa dirumuskan sebagai berikut:

Persentase per-soal $=\frac{\text { jumlah benar per-soal }}{\text { Jumlah Sampel }} \times 100 \%$

Maka akan mendapatkan hasil sebagai berikut:

\begin{tabular}{|c|c|c|}
\hline No Urut Soal & Jumlah Benar & Persentase \\
\hline 1. & 10 & $83 \%$ \\
\hline 2. & 12 & $100 \%$ \\
\hline 3. & 12 & $100 \%$ \\
\hline 4. & 10 & $83 \%$ \\
\hline 5. & 9 & $75 \%$ \\
\hline 6. & 6 & $50 \%$ \\
\hline 7. & 10 & $83 \%$ \\
\hline 8. & 9 & $75 \%$ \\
\hline 9. & 9 & $75 \%$ \\
\hline 10. & 10 & $83 \%$ \\
\hline
\end{tabular}


Penerapan Linguistik Arab... (Abdul Kosim)

\begin{tabular}{|c|c|c|}
\hline 11. & 11 & $92 \%$ \\
\hline 12. & 10 & $83 \%$ \\
\hline 13. & 10 & $83 \%$ \\
\hline 14. & 3 & $25 \%$ \\
\hline 15. & 9 & $75 \%$ \\
\hline 16. & 9 & $17 \%$ \\
\hline 17. & 9 & $75 \%$ \\
\hline 18. & 10 & $75 \%$ \\
\hline 19. & 11 & $92 \%$ \\
\hline 20. & & \\
\hline
\end{tabular}

Maka dapat dilihat dalam tabel tersebut bahwasannya hampir semua responden mampu menjawab soal-soal yang peneliti berikan, hanya beberapa soal saja yang mempunyai persentase rendah.

2. Persentase per- Sampel

Persentase per-sampel atau per-orang ini dihitung untuk mengetahui persentase kemampuan responden dalam mengisi soal secara perorangan atau individu. Untuk mengetahui persentase tersebut peneliti harus mengetahui jumlah benar yang didapat oleh setiap sampelnya, kemudian dibagi dengan jumlah soal yang kemudian akan dihitung persennya. Atau bisa dirumuskan sebagai berikut:

Persentase per-sampel $=\frac{\text { Jumlah benar per-sampel }}{\text { Jumlah Soal }} \times 100 \%$

\begin{tabular}{|c|c|c|}
\hline Sampel & Jumlah benar & Persentase \\
\hline 1. & 4 & $20 \%$ \\
\hline 2. & 12 & $60 \%$ \\
\hline
\end{tabular}


Kalamuna, Vol. 1. No. 1 Juli 2020, 20 - 37

\begin{tabular}{|c|c|c|}
\hline 3. & 18 & $90 \%$ \\
\hline 4. & 19 & $95 \%$ \\
\hline 5. & 16 & $80 \%$ \\
\hline 6. & 19 & $95 \%$ \\
\hline 7. & 18 & $90 \%$ \\
\hline 8. & 17 & $85 \%$ \\
\hline 9. & 19 & $95 \%$ \\
\hline 10. & 9 & $45 \%$ \\
\hline 11. & 18 & $70 \%$ \\
\hline 12. & & \\
\hline Jumlah & 182 & \\
\hline
\end{tabular}

Dapat dilihat persentase kemampuan setiap sampel atau responden dikatakan sangat baik karena hanya beberapa yang persentasenya rendah.

3. Persentase secara Keseluruhan

Persentase secara keseluruhan ini dihitung agar diketahui seberapa persen kemampuan seluruh guru bahasa Arab di kabupaten Purwakarta dalam memahami linguistik Arab. Untuk mengetahui persentase tersebut maka harus diketahui jumlah perolehan seluruh sampel, jumlah perolehan seluruh sampel bisa dilihat di tabel sebelumnya, yaitu ada 182 jawaban, atau bisa dihitumg dengan rumus sebagai berikut:

Persentase keseluruhan $=\frac{\text { Jumlah benar semua sampel }}{\text { skor } \max } \times 100 \%$

Persentase keseluruhan $=\frac{182}{240} \times 100 \%$

$=76 \%$

Dari hasil tersebut diketahui bahwa persentase penerapan linguistik Arab dalam memahami Al- Qur'an pada seluruh guru bahasa Arab di kabupaten Purwakarta 
memperoleh hasil sebesar 76\%. Hasil ini menunjukkan angka yang sangat besar dan memuaskan yang menggambarkan tentang kualitas guru Bahasa Arab Madrasah Aliyah Kabupaten Purwakarta.

4. Persentase setiap Kategori Soal

Di atas telah dijelaskan perolehan persentase secara keseluruhan, maka dari perolehan itu dapat diketahui apa saja yang mencakup 76\%. Maka dari itu dapat dihitung dengan cara mengetahui persentase setiap kategori soal.

Persentase setiap kategori soal merupakan persentase untuk mengetahui seberapa persen pemahaman responden terhadap kategori- kategori tersebut.

Sebagaimana yang telah diketahui bahwa kategori soal yang diajukan terhadap responden meliputi kategori fonologi, sintaksis, morfologi dan semantik. Untuk mengetahui persentase tersebut maka harus dihitung jumlah jawaban yang benar dari setiap kategori, lalu dikalikan dengan jumlah maksimal setiap kategori, kemudian harus diketahui juga jumlah persen maksimal dari setiap kategori. Bisa dihitung jikalau 20 soal adalah $100 \%$, maka setiap soal bernilai 5\%, sedangkan setiap kategori meliputi 5 soal, maka setiap kategori bernilai 25\%. Atau bisa dilihat untuk mengetahui persentase setiap kategori yang telah diperoleh, dapat menggunakan rumus tersebut:

Persentase kategori $=\frac{\text { Jumlah benar setiap kategori }}{\text { skor } \max \text { setiap } \text { kategori }} \times 25 \%$

Fonologi $=\frac{53}{60} \times 25 \%=22 \%$

Sintaksis $=\frac{44}{60} \times 25 \%=18,3 \%$

Morfologi $=\frac{44}{60} \times 25 \%=18,3 \%$

Semantik $=\frac{41}{60} \times 25 \%=17 \%$

Dari perhitungan di atas dapat diketahui dari jumlah persentase penerapan linguistik Arab dalam memahami Al- Qur'an pada seluruh guru bahasa Arab di kabupaten Purwakarta yang berjumlah 76\% dapat terbagi menjadi empat kategori, yaitu kategori fonologi yang bernilai $22 \%$, kategori sintaksis yang bernilai 18,3\%, kategori morfologi yang bernilai $18,3 \%$, dan kategori semantik yang bernilai $17 \%$.

\section{E. Penutup}


Berdasarkan hasil penelitian yang telah dilakukan dapat ditarik kesimpulan bahwa tidak ditemukan problematika yang signifikan pada guru bahasa Arab di Purwakarta dalam memahami bahasa Al-Quran, hal ini dibuktikan dengan data yang menunjukkan pemahaman $76 \%$ dari jumlah responden dalam menjawab pertanyaan yang berkaitan dengan kategori fonologi, sintaksis, morfologi dan semantik dengan rincian sebagai berikut, yaitu kategori fonologi bernilai $22 \%$, kategori sintaksis yang bernilai $18,3 \%$, kategori morfologi yang bernilai 18,3\%, dan kategori semantik yang bernilai $17 \%$.

\section{Daftar Pustaka}

Al-Khuli, Muhammad Ali. 1991. A Dictionary of Theoretical Linguistics. Beirut: Librarie di Liban

Al-Qathan, Manna Khalil. 2005. Mabahits fi Ulum Al-Qur'an, Terjemahan Aunur Rafiq El-Mazni. Jakarta Timur: Pustaka Al-Kautsar

Al-Qathan, Manna Khalil. Mabahits fi Ulum Al-Qur'an, Terjemahan Mudzakir As.Jakarta: Litera Antarnusa

Ar -Rahman.2012. Al-Qur'an Perkata Indonesia-Inggris. Jakarta: Kalam Media Ilmu

As-Samira'i, Fadhil Shalil. 2006. Balaghatu Al-Kalimat Fi At-Ta'biri Al-Qur'ani. Bagdad: Universitas Al-Azhar

Djajasudarma, T. Fatimah. 2012. Semantik 1. Bandung: Refika Aditamu

Jinni, Ibnu. 1913. Al-Khasa'is. Mesir: Daar Al-Kutub

Kementrian Agama RI. 2012. Alquran dan Terjemahnya. Jakarta: KEMENAG

Kridalaksana, Harimurti. 2008. Kamus Linguistik. Jakarta: PT. Gramedia Pustaka Utama

Marlina, Lina. 2019. Pengantar Ilmu Ashwat. Bandung: Fajar Media

Nandang, Ade Dkk.2018. Pengantar Linguistik Arab. Bandung: PT Remaja Rosdakarya

Nata, Abudin. 2012. Metodologi Studi Islam. Depok: PT. Rajagrafindo Persada

Nur, Tajudin. 2018. Sintaksis Bahasa Arab. Sumedang: Unpad Press

Nur, Tajudin. 2017. Semantik Bahasa Arab. Bandung: Semiotika 
Penerapan Linguistik Arab... (Abdul Kosim)

Qalyubi, Syihabuddin. 2013. Stilistika Bahasa dan Sastra Arab. Yogyakarta: Karya Media

Shihab, M. Quraish . 2013. Kaidah Tafsir. Tanggerang: Lentera Hati

Suma, Muhammad Amin. Ulumul Qur'an. Jakarta: Rajawali Press

Sunendar, Dadang. 2016. Pedoman Umum Ejaan Bahasa Indonesia. Jakarta: Badan Pengembangan dan Pembinaan Bahasa KEMENDIKBUD

Ukasah, Mahmud. 2011. At-Tahlil Al-Lughawy. Daar Ibnu Hazm 